\title{
PERBANDINGAN PENINGKATAN KEMAMPUAN PEMAHAMAN DAN KOMUNIKASI MATEMATIS ANTARA SISWA YANG MENGGUNAKAN MODEL PEMBELAJARAN THINK TALK WRITE DAN SISWA YANG MENGGUNAKAN MODEL DIRECT INSTRUCTION
}

\author{
Nandang Kusnandar \\ nandang315@gmail.com \\ STKIP Sebelas April Sumedang
}

\begin{abstract}
ABSTRAK
Penelitian ini bertujuan untuk mengetahui pengaruh dan perbandingan penggunaan model pembelajaran think talk write dan model direct instruction terhadap pencapaian kemampuan pemahaman dan komunikasi matematis siswa pada materi keliling dan luas persegi dan persegi panjang. Untuk mengetahui pencapaian kemampuan pemahaman dan komunikasi matematis siswa pada kelas eksperimen I yang menggunakan model pembelajaran think talk write dan kelas eksperimen II yang menggunakan model direct instruction maka dilakukan penelitian kuasi eksperimen dengan menggunakan desain penelitian Nonequivalent Control Group Design. Subjek penelitian adalah siswa kelas III (tiga) SD di Kabupaten Sumedang yang berjumlah 52 orang siswa yang terbagi dalam 2 kelas masing-masing berjumlah 26 orang siswa. Perlakuan (treatment) dilakukan sebanyak enam pertemuan pada setiap kelas eksperimen I dan kelas eksperimen II. Instrumen yang digunakan dalam penelitian ini berupa tes berbentuk uraian baik untuk kemampuan pemahaman maupun kemampuan komunikasi matematis siswa. Berdasarkan hasil perhitungan persentase skor rata-rata pretest dan posttest kemampuan pemahaman matematis pada kelas think talk write didapat peningkatan sebesar 18,34\% dan kelas direct instruction sebesar 21,3\%. Sedangkan untuk kemampuan komunikasi matematis pada kelas think talk write didapat peningkatan sebesar 19,23\% dan kelas direct instruction sebesar $17,58 \%$. Hasil perhitungan statistik parametrik dengan uji perbedaan dua rata-rata independen (uji-t) menunjukkan bahwa tidak terdapat perbedaan yang signifikan mengenai peningkatan kemampuan pemahaman dan kemampuan komunikasi matematis siswa antara kelas eksperimen I yang menggunakan model pembelajaran think talk write dan kelas eksperimen II yang menggunakan model direct instruction. Berdasarkan hasil penelitian dapat disimpulkan bahwa kedua kelas eksperimen memiliki efektivitas yang sama baik pada kemampuan pemahaman matematis maupun kemampuan komunikasi matematis siswa.
\end{abstract}

Kata kunci: pemahaman matematis, komunikasi matematis, model pembelajaran think talk write, dan model direct instruction. 


\section{A. PENDAHULUAN}

Pendidikan bertujuan untuk mengembangkan individu baik jasmani maupun rohani secara optimal agar mampu meningkatkan hidup, kehidupan diri, keluarga, dan masyarakatnya. Dalam UU No. 20 tahun 2003 tentang Sistem Pendidikan Nasional Bab II Pasal 3 disebutkan bahwa Pendidikan Nasional bertujuan untuk mengembangkan potensi peserta didik agar menjadi manusia yang beriman dan bertakwa kepada Tuhan Yang Maha Esa, berakhlak mulia, sehat, berilmu, cakap, kreatif, mandiri, dan menjadi warga Negara yang demokratis serta bertanggung jawab. Hal ini setara dengan yang diungkapkan dalam dictionary of education yang menyebutkan bahwa pendidikan adalah proses dimana seseorang mengembangkan sikap dan bentuk-bentuk tingkah laku lainnya di dalam masyarakat, proses sosial ketika seseorang dihadapkan pada lingkungan yang terpilih dan terkontrol, sehingga seseorang itu dapat mengembangkan kemampuan sosial dan individunya secara optimal . Rumusan tujuan Pendidikan Nasional merupakan rujukan utama untuk penyelenggaraan pembelajaran bidang studi apapun, termasuk bidang studi matematika sekolah dasar.

Memahami dan mampu menggunakan matematika di dalam kehidupan sehari-hari dan di dalam dunia kerja sangatlah penting. Pentingnya penguasaan matematika terlihat pada Undang-Undang RI No. 20 Th. 2003 tentang Sisdiknas Pasal 37 yang menegaskan bahwa mata pelajaran matematika merupakan salah satu mata pelajaran wajib bagi siswa pada jenjang pendidikan dasar dan menengah. Soedjadi (2000, hlm. 29) menyatakan bahwa wujud dari pelajaran matematika di pendidikan dasar dan menengah adalah matematika sekolah. Matematika sekolah adalah unsur-unsur atau bagian-bagian dari matematika yang dipilih berdasarkan kepentingan pendidikan untuk menguasai teknologi dimasa depan. Menurut Wahyudin (2012), enam prinsip untuk matematika sekolah menyoroti tema-tema: 1) keadilan. Keunggulan mutu di dalam pendidikan matematika menuntut keadilan, harapan-harapan tinggi, dan dukungan kuat untuk semua siswa; 2) kurikulum. Suatu kurikulum lebih dari hanya sekedar sekumpulan kegiatan, kurikulum harus koheren, berfokus pada matematika yang penting, serta diartikulasikan secara baik dari setiap tingkat kelas; 3) pengajaran. Pengajaran matematika yang efektif menuntut pemahaman atas apa yang siswa ketahui dan perlu pelajari kemudian mendukung mereka untuk mempelajarinya dengan baik; 4) belajar. Siswa harus mempelajari matematika bersama pemahaman, secara aktif membangun pengetahuan baru dari pengetahuan dan pengalaman sebelumnya; 5) assessment. Assessment harus mendukung dipelajarinya matematika yang penting serta memberikan keterangan yang 
berguna bagi siswa dan guru; 6) teknologi. Teknologi mempengaruhi matematika yang diajarkan dan mempertinggi belajar siswa.

Mata pelajaran matematika yang diberikan di pendidikan dasar dan menengah juga dimaksudkan untuk membekali siswa dengan kemampuan berpikir logis, analitis, sistematis, kritis, dan kreatif, serta kemampuan bekerjasama. Kemampuan tersebut, merupakan kompetensi yang diperlukan oleh siswa agar dapat memiliki kemampuan memperoleh, mengelola, dan memanfaatkan informasi untuk bertahan hidup pada keadaan yang selalu berubah, tidak pasti, dan kompetitif. Seiring dengan perkembangan ilmu pengetahuan dan teknologi, peran matematika sebagai salah satu ilmu dasar yang memiliki nilai esensial yang dapat diterapkan dalam berbagai bidang kehidupan menjadi sangatlah penting (Wahyudin, 2012).

Mencermati peran matematika seperti itu, maka dirumuskan tujuan pembelajaran matematika di sekolah menurut Permendiknas No. 22 (Depdiknas, 2006) hendaklah meliputi hal berikut: (1) memahami konsep matematika, menjelaskan keterkaitan antar konsep dan mengaplikasikan konsep atau algoritma, secara luas, akurat, efisien, dan tepat dalam pemecahan masalah; (2) menggunakan pemahaman pada pola dan sifat, melakukan manipulasi matematikadalam membuat generalisasi, menyusun bukti, atau menjelaskan gagasan dan pernyataan matematika; (3) memecahkan masalah yang meliputi kemampuan memahami masalah, merancang model matematika, menyelesaikan model dan menafsirkan solusi yang diperoleh; (4) mengkomunikasikan gagasan dengan simbol, tabel, diagram, atau media lain untuk memperjelas keadaan atau masalah; (5) memiliki sikap menghargai kegunaan matematika dalam kehidupan, yaitu memiliki rasa ingin tahu, perhatian dan minat dalam mempelajari matematika, serta sikap ulet dan percaya diri dalam pemecahan masalah.

Berdasarkan tujuan tersebut, dapat dikatakan bahwa belajar matematika tidak cukup dengan hanya menyampaikan materi pelajaran sesuai dengan tuntutan kurikulum, tetapi harus disertai dengan makna di mana siswa dapat menggunakan kemampuan dan rasa ingin tahunya dengan leluasa dan tanpa tekanan. Hal ini sudah selayaknya menjadi konsep atau cara pandang guru yang modern dalam proses belajar mengajar, karena pada hakikatnya matematika tidak terletak pada penguasaan matematika sebagai ilmu tetapi bagaimana menggunakan matematika itu dalam mencapai keberhasilan hidup di masa yang akan datang.

Pembelajaran matematika yang diharapkan muncul adalah kemampuan memahami konsep matematika itu sendiri. Siswa yang memiliki pemahaman konsep yang bagus akan mengetahui lebih dalam tentang ide-ide matematika yang masih terselubung. Pengetahuan 
yang dipelajari dengan pemahaman akan memberikan dasar dalam pembentukan pengetahuan baru sehingga dapat digunakan dalam memecahkan masalah-masalah baru, setelah terbentuknya pemahaman dari sebuah konsep, siswa dapat memberikan pendapat, menjelaskan suatu konsep (Sumarmo, 1987). Hal ini memberikan pengertian bahwa materimateri yang diajarkan kepada siswa bukan hanya sebagai hafalan sebagaimana yang diungkapkan oleh Marpaung (1999, hlm. 16) matematika tidak ada artinya bila hanya dihafalkan, namun lebih dari itu dengan pemahaman siswa dapat lebih mengerti akan konsep materi pelajaran itu sendiri.

Wardhani (2008, hlm. 37), menjelaskan indikator-indikatornya sebagai acuan dalam hasil belajar matematika dari kemampuan pemahaman konsep diantaranya sebagai berikut.

1. Kemampuan menyatakan ulang konsep.

2. Kemampuan mengklasifikasikan objek menurut sifat-sifat tertentu sesuai dengan konsepnya.

3. Kemampuan memberi contoh dan bukan contoh.

4. Kemampuan menyajikan konsep dalam berbagai bentuk representasi matematis.

5. Kemampuan mengembangkan syarat perlu atau syarat cukup dari suatu konsep.

6. Kemampuan mengaplikasikan konsep atau algoritma ke pemecahan masalah.

Selain memberi prioritas pada pengembangan kemampuan pemahaman dalam upaya mengembangkan sikap ilmiah siswa, juga diperlukan adanya kemampuan komunikasi. Komunikasi adalah bagian esensial dari matematika dan pendidikan matematika (Wahyudin, 2012, hlm. 42).Pengembangan komunikasi juga menjadi salah satu tujuan pembelajaran matematika dan menjadi salah satu standar kompetensi lulusan dalam bidang matematika. Melalui pembelajaran matematika, siswa diharapkan dapat mengkomunikasikan gagasan dengan simbol, tabel, diagram, atau media lain untuk memperjelas keadaan atau masalah (Permen Nomor 23 Tahun 2006). Melalui komunikasi, seseorang akan dapat mengungkapkan gagasan, temuan atau bahkan perasaannya terhadap orang lain. Siswa yang mendapatkan kesempatan-kesempatan, dorongan, dan dukungan untuk berbicara, menulis, membaca, dan menyimak di dalam kelas matematika akan memperoleh keuntungan ganda: mereka berkomunikasi untuk belajar matematika, dan belajar untuk berkomunikasi secara matematis (Wahyudin, 2012, hlm. 43).

Kemampuan komunikasi matematis menurut para ahli dapat dikelompokkan menjadi tiga, yaitu: 1) Written Text, yaitu memberikan jawaban dengan menggunakan bahasa sendiri, membuat model situasi atau persoalan menggunakan tulisan, konkrit, grafik dan aljabar, 
menjelaskan dan membuat pertanyaan tentang matematika yang telah dipelajari, mendengarkan, mendiskusikan dan menulis tentang matematika, membuat konjektur, menyusun argumen dan generalisasi; 2) Drawing, yaitu merefleksikan benda-benda nyata, gambar dan diagram ke dalam ide-idematematik; 3) Mathematical Expression, yaitu mengekspresikan konsep matematika dengan menyatakan peristiwa sehari-hari dalam bahasa atau simbol matematika.

Peningkatan kemampuan pemahaman dan komunikasi siswa dapat dilakukan dengan mengadakan perubahan-perubahan dalam pembelajaran. Dalam hal ini, perlu dirancang suatu pembelajaran yang membiasakan siswa untuk mengkonstruksi sendiri pengetahuannya, sehingga siswa lebih memahami konsep yang diajarkan serta mampu mengkomunikasikan pemikirannya baik dengan guru, teman maupun terhadap materi matematika itu sendiri.

Salah satu cara yang dapat dilakukan untuk meningkatkan pemahaman dan kemampuan komunikasi matematika siswa adalah dengan melaksanakan model pembelajaran yang menuntut peran aktif siswa dalam proses pembelajaran (Hamzah \& Muhlisrarini, 2014). Agar siswa bisa termotivasi, menyenangi belajar matematika dan mempunyai sikap positif terhadap matematika serta dapat meningkatkan kemampuan pemahaman dan komunikasi matematika, maka diperlukan upaya untuk menciptakan suatu pembelajaran yang menyenangkan siswa dalam belajar.

\section{B. Model Pembelajaran Think Talk Write}

Huinker dan Laughin (1996, hlm. 82) menyatakan bahwa think talk write membangun pemikiran , merefleksi, dan mengorganisasi ide, kemudian menguji ide tersebut sebelum siswa diharapkan untuk menulis. Alur kemajuan model think talk write dimulai dari keterlibatan siswa dalam berpikir atau berdialog reflektif dengan dirinya sendiri, selanjutnya berbicara dan berbagi ide dengan temannya, sebelum siswa menulis.

Menurut Porter (1992, hlm. 179) bahwa think talk write adalah pembelajaran dimana siswa diberikan kesempatan untuk memulai belajar dengan memahami permasalahan terlebih dahulu, kemudian terlibat secara aktif dalam diskusi kelompok, dan akhirnya menuliskan dengan bahasa sendiri hasil belajar yang diperolehnya. Alur pembelajaran think talk write dimulai dari fase think, siswa diminta membaca, membuat catatan kecil secara individual dari apa yang diketahui atau tidak diketahui untuk dibawa pada forum diskusi. Selanjutnya fase talk yaitu berbicara dan membagi ide (sharing) dengan temannya dalam forum diskusi sebelum menulis. Suasana seperti ini lebih efektif jika dilakukan dalam kelompok heterogen 
antara 3-5 orang siswa. Setelah siswa diminta membaca, membuat catatan kecil, menjelaskan, mendengar, dan membagi ide bersama teman, kemudian mengungkapkannya melalui tulisan (write). Aktivitas berpikir, berbicara, dan menulis adalah salah satu bentuk aktivitas belajarmengajar matematika yang memberikan peluang kepada siswa untuk berpartisipasi aktif. Melalui aktivitas tersebut siswa dapat mengembangkan kemampuan berbahasa secara tepat, terutama saat menyampaikan ide-ide matematika.

\section{Model Direct Instruction}

Model direct instruction dilandasi oleh teori belajar perilaku yang berpandangan bahwa belajar bergantung pada pengalaman termasuk pemberian umpan balik. Satu penerapan teori perilaku dalam belajar adalah pemberian penguatan. Umpan balik kepada siswa dalam pembelajaran merupakan penguatan yang merupakan penerapan teori perilaku tersebut (Arends, 2007).

Model pengajaran langsung dirancang secara khusus untuk mengembangkan pengetahuan prosedural dan pengetahuan deklaratif. Pengetahuan deklaratif adalah pengetahuan tentang sesuatu sedangkan pengetahuan prosedural adalah pengetahuan tentang bagaimana melakukan sesuatu yang keduanya berstruktur dengan baik dapat dipelajari selangkah demi selangkah.

Beberapa keunggulan terpenting dari pembelajaran langsung ini adalah adanya fokus akademik, arahan dan kontrol guru, harapan yang tinggi terhadap perkembangan siswa, sistem manajemen waktu, dan atmosfer akademik yang cukup netral (Joyce, Weil, \& Calhoun, 2009). Fokus akademik berarti prioritas tertinggi yang diletakkan dalam penugasan dan penyelesaian tugas akademik. Arahan dan kontrol guru diberikan saat guru memilih dan mengarahkan tugas pembelajaran, menegaskan peran inti selama memberi instruksi, dan meminimalisir jumlah percakapan siswa yang tidak berorientasi akademik. Guru memiliki pengharapan yang tinggi pada siswa-siswanya serta concern dalam bidang tersebut akan berusaha menghasikan kemajuan akademik yang istimewa serta perilaku kondusif demi terciptanya kemajuan dalam pendidikan. Pengajaran langsung berpegang teguh pada asumsi bahwa sebagian besar yang dipelajari berasal dari mengamati orang lain. Belajar dengan meniru tingkah laku orang lain dapat menghemat waktu, menghindarkan siswa dari belajar melalui coba-coba atau trial and error.

Dua tujuan utama dari direct instruction adalah memaksimalkan waktu belajar siswa dan mengembangkan kemandirian dalam mencapai dan mewujudkan tujuan pembelajaran. 
Perilaku-perilaku guru yang tampak berhubungan dengan prestasi siswa sesungguhnya juga berhubungan dengan waktu yang dimiliki siswa dan taraf kesuksesan mereka dalam mengerjakan tugas yang pada gilirannya juga berubungan erat dengan prestasi siswa. Pada akhirnya, guru harus menghindari perilaku yang akan berpengaruh negatif terhadap prestasi dan pencapaian siswa, seperti mencela perilaku siswa (Joyce, Weil, \& Calhoun, 2009).

Tahapan atau sintaks model pembelajaran langsung menurut Joyce, Weil, dan Calhoun (2009, hlm. 428), adalah sebagai berikut.

Tahap Pertama: Orientasi. Sebelum menyajikan dan menjelaskan materi baru, akan sangat menolong siswa jika guru memberikan kerangka pelajaran dan orientasi terhadap materi yang akan disampaikan.

Tahap Kedua: Presentasi. Pada fase ini guru dapat menyajikan materi pelajaran baik berupa konsep-konsep maupun keterampilan.

Tahap Ketiga: Latihan terstruktur. Pada fase ini guru memandu siswa untuk melakukan latihan-latihan. Peran guru yang penting dalam fase ini adalah memberikan umpan balik terhadap respon siswa dan memberikan penguatan terhadap respon siswa yang benar dan mengoreksi respon siswa yang salah.

Tahap keempat: Latihan terbimbing. Pada fase ini guru memberikan kesempatan kepada siswa untuk berlatih konsep atau keterampilan. Latihan terbimbing ini baik juga digunakan oleh guru untuk mengases/menilai kemampuan siswa untuk melakukan tugasnya. Pada fase ini peran guru adalah memonitor dan memberikan bimbingan jika diperlukan.

Tahap Kelima: Latihan mandiri. Pada fase ini siswa melakukan kegiatan latihan secara mandiri, fase ini dapat dilalui siswa jika telah menguasai tahap-tahap pengerjaan tugas 8590\% dalam fase bimbingan latihan.

\section{Hipotesis Penelitian}

Berdasarkan uraian di atas, hipotesis penelitian ini adalah sebagai berikut.

a. Terdapat perbedaan peningkatan kemampuan pemahaman matematis antara siswa yang menggunakan model pembelajaran think talk write dengan siswa yang menggunakan model direct instruction.

b. Terdapat perbedaan peningkatan kemampuan komunikasi matematis antara siswa yang menggunakan model pembelajaran think talk write dengan siswa yang menggunakan model direct instruction. 
c. Pengaruh (effect size) model pembelajaran think talk write dan model direct instruction terhadap kemampuan pemahaman matematis siswa termasuk klasifikasi besar.

d. Pengaruh (effect size) model pembelajaran think talk write dan model direct instruction terhadap kemampuan komunikasi matematis siswa termasuk klasifikasi besar.

\section{E. Metode dan Desain Penelitian}

Penelitian ini dilaksanakan dengan menggunakan metode penelitian eksperimen semu (quasi experiment). Metode ini memiliki karakteristik yaitu mengkaji keadaan praktis suatu objek, yang didalamnya tidak mungkin untuk mengontrol semua variabel yang relevan kecuali variabel-variabel yang diteliti (Panggabean, 1996). Metode ini dipandang cocok untuk penelitian pendidikan, mengingat faktor yang dipredikasi berpengaruh terhadap hasil penelitian yang tidak dapat atau sulit untuk dikontrol. Dalam penelitian ini, subyek yang akan diteliti merupakan siswa-siswa yang sudah terdaftar dengan kelasnya masing-masing, sehingga tidak dimungkinkan untuk membuat kelompok baru secara acak. Sebagaimana yang dikemukakan oleh Ruseffendi (2006) bahwa pada quasi eksperimen subyek tidak dikelompokkan secara acak, tetapi peneliti menerima keadaan subyek apa adanya.

Pada penelitian ini, ada dua kelompok subyek penelitian yaitu kelompok eksperimen I dan kelompok eksperimen II. Kelompok eksperimen I mendapat perlakuan pembelajaran matematika dengan menggunakan model pembelajaran think talk write dan kelompok eksperimen II mendapat perlakuan pembelajaran matematika dengan menggunakan model direct instruction. Kedua kelompok diberikan pretest dan posttest dengan menggunakan instrumen tes yang sama. Desain eksperimen yang digunakan dalam penelitian ini adalah desain nonequivalent control group design (Sugiono, 2014).

Pengembangan instrumen kemampuan pemahaman dan komunikasi matematis siswa dilakukan dengan tahap-tahap sebagai berikut: 1) menyusun kisi-kisi soal, 2) melakukan uji coba instrumen, 3) melakukan analisis butir soal. Analisis butir soal dilakukan dengan cara uji coba instrumen untuk menguji validitas soal, reliabilitas soal, tingkat kesukaran, dan daya pembeda. Hal ini juga disarankan Tandiling (2012) melalui penelitian yang dilakukannya menyarankan agar instrumen yang dipakai baik untuk pengambilan data penelitian maupun untuk mengukur hasil belajar siswa sebaiknya terlebih dahulu ditentukan validitas dan reliabilitasnya agar data yang akan dikumpulkan tidak menjadi bias atau menyimpang.

Tabel 1. Hasil Uji Coba Soal Tes Kemampuan

\begin{tabular}{|l|c|c|c|c|} 
Nomor & Validitas & Tingkat Kesukaran & Daya Pembeda & Reliabilitas \\
\hline
\end{tabular}




\begin{tabular}{|c|c|c|c|c|c|c|c|}
\hline Soal & Nilai & Kategori & Nilai & Kategori & Nilai & Kriteria & \\
\hline 1 & 0,597 & Valid & 0,692 & Sedang & 0,231 & Cukup & \multirow{10}{*}{$\begin{array}{c}\mathbf{0 , 8 4 2} \\
\text { Kategori: } \\
\text { SangatTinggi }\end{array}$} \\
\hline 2 & 0,645 & Valid & 0,564 & Sedang & 0,205 & Cukup & \\
\hline 3 & 0,619 & Valid & 0,885 & Mudah & 0,231 & Cukup & \\
\hline 4 & 0,773 & Valid & 0,462 & Sedang & 0,205 & Cukup & \\
\hline 5 & 0,694 & Valid & 0,577 & Sedang & 0,231 & Cukup & \\
\hline 6 & 0,601 & Valid & 0,731 & Mudah & 0,231 & Cukup & \\
\hline 7 & 0,787 & Valid & 0,260 & Sukar & 0,212 & Cukup & \\
\hline 8 & 0,653 & Valid & 0,513 & Sedang & 0,205 & Cukup & \\
\hline 9 & 0,644 & Valid & 0,885 & Mudah & 0,231 & Cukup & \\
\hline 10 & 0,681 & Valid & 0,436 & Sedang & 0,205 & Cukup & \\
\hline
\end{tabular}

Dari perhitungan hasil uji coba instrumen yang telah dilakukan, baik uji validitas, reliabilitas, tingkat kesukaran, maupun daya pembeda, dapat disimpulkan bahwa soal-soal tes kemampuan pemahaman dan komunikasi matematis siswa dapat digunakan, sehingga jumlah soal yang akan digunakan untuk penelitian (pretest dan posttest) berjumlah 10 soal uraian.

Dalam pengumpulan data, teknik penelitian yang akan digunakan adalah tes kemampuan pemahaman dan komunikasi matematis dalam bentuk uraian. Peningkatan kemampuan pemahaman dan komunikasi matematis ditinjau berdasarkan perbandingan nilai gain yang dinormalisasi ( $N$-gain) antara kelompok eksperimen I dan kelompok eksperimen II. Besarnya pengaruh model pembelajaran terhadap kemampuan pemahaman dan komunikasi matematis dianalisis menurut analisis effect size Cohen.

Effect size adalah ukuran kuantitatif dari perbedaan antara dua kelompok yang diteliti (Cohen dalam Becker, 2000). Dalam tinjauan sistematis dan meta analisis dari intervensi, effect size dihitung berdasarkan perbedaan standar rata-rata antara dua kelompok yang diteliti, yaitu perbedaan antara skor rata-rata hasil posttest kelompok eksperimen I dan kelompok eksperimen II.

\section{F. Analisis Kemampuan Pemahaman dan Komunikasi Matematis Siswa}

Analisis kemampuan pemahaman dan komunikasi matematis siswa pada penelitian ini terdiri dari analisis perbandingan skor pretest dan posttest, analisis peningkatan kemampuan matematis siswa, dan analisis pengaruh model pembelajaran terhadap kemampuan pemahaman dan komunikasi matematis siswa.

\section{Perbandingan Skor Pretest dan Posttest}

Kemampuan pemahaman dan komunikasi matematis siswa pada materi keliling dan luas persegi dan persegi panjang, diukur dengan tes berbentuk uraian sebanyak 10 soal yang 
terdiri dari 5 soal yang berkaitan dengan pemahaman matematis serta 5 soal yang berkaitan dengan komunikasi matematis siswa.

\section{Hasil Tes Kemampuan Pemahaman Matematis Siswa (\%)}

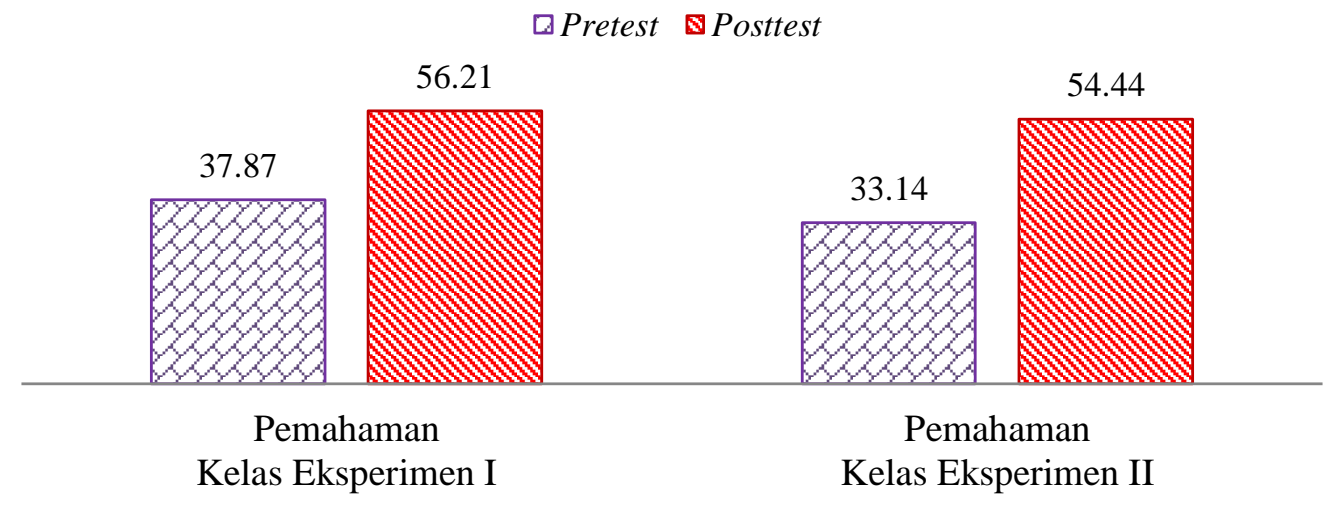

Gambar 1. Skor Pretest dan Posttest Kemampuan Pemahaman Matematis Siswa

Dari gambar 1. terlihat bahwa perbedaan persentase skor hasil pretest kemampuan pemahaman matematis siswa untuk materi keliling dan luas persegi dan persegi panjang pada kelas eksperimen I dan kelas eksperimen II sebesar 37,87\% - 33,14\% = 4,73\%, dengan rincian siswa yang berada di kelas eksperimen I persentasenya lebih besar daripada siswa yang berada di kelas eksperimen II.

Skor hasil posttest setelah perlakuan memperlihatkan kenaikan persentase skor dari kedua kelas yang diteliti. Untuk skor hasil posttest kemampuan pemahaman matematis, siswa pada kelas eksperimen I mendapatkan persentase yang lebih besar daripada siswa pada kelas eksperimen II, walaupun perbedaannya tidak terlalu besar, yaitu sebesar 56,21\% - 54,44\% = $1,77 \%$.

\section{Hasil Tes Kemampuan Komunikasi Matematis Siswa (\%)}

$\square$ Pretest $\square$ Posttest

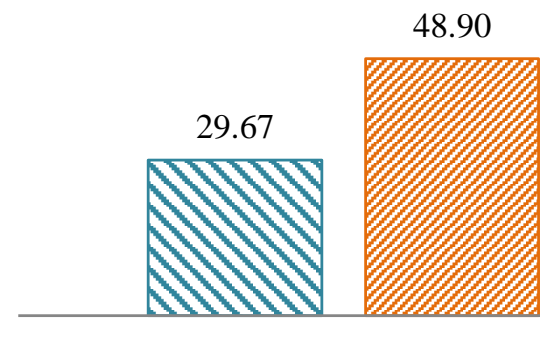

Komunikasi

Kelas Eksperimen I

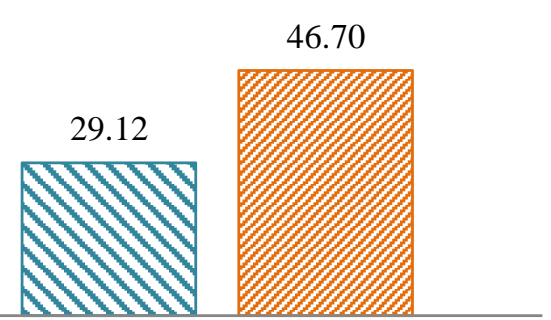

Komunikasi

Kelas Eksperimen II 
Gambar 2. Skor Pretest dan Posttest Kemampuan Komunikasi Matematis

Siswa

Berdasarkan gambar 2. terlihat bahwa perbedaan persentase skor hasil pretest kemampuan komunikasi matematis siswa untuk materi keliling dan luas persegi dan persegi panjang pada kelas eksperimen I dan kelas eksperimen II sebesar29,67\% - 29,12\% $=0,55 \%$, dengan siswa yang berada di kelas eksperimen I persentasenya lebih besar daripada siswa yang berada di kelas eksperimen II.

Skor hasil posttest setelah perlakuan memperlihatkan kenaikan persentase skor dari kedua kelas yang diteliti. Perbedaan persentase skor hasil posttest kemampuan komunikasi matematis siswa pada kelas eksperimen I dan kelas eksperimen II sebesar 48,90\% - 46,70\% = $2,20 \%$, dengan rincian siswa yang berada di kelas eksperimen I persentasenya lebih besar daripada siswa yang berada di kelas eksperimen II, walaupun perbedaan itu tidak terlalu besar.

\section{Peningkatan Kemampuan Pemahaman dan Komunikasi Matematis Siswa}

Pengujian statistik untuk mengetahui perbandingan peningkatan kemampuan pemahaman dan komunikasi matematis siswa dilakukan dengan uji normalitas, homogenitas, dan uji hipotesis dengan menggunakan gain ternormalisasi (n-gain) antara kedua kelas yang diteliti.

Tabel 2. Rekapitulasi Analisis Hasil N-Gain Kemampuan Pemahaman Matematis Siswa

\begin{tabular}{|c|c|c|}
\hline Komponen Peninjau & $\begin{array}{c}\text { Think Talk Write } \\
\text { (Kelas Eksperimen I) }\end{array}$ & $\begin{array}{c}\text { Direct Instruction } \\
\text { (Kelas Eksperimen II) }\end{array}$ \\
\hline Jumlah Siswa & 26 & 26 \\
\hline$\sum$ g & 7,437 & 8,102 \\
\hline Rata-rata & 0,2860 & 0,3116 \\
\hline Standar Deviasi & 0,1107 & 0,0869 \\
\hline Uji Normalitas (Lilliefors) dengan Lhitung $<\mathbf{L}_{\text {tabel }}\left(\boldsymbol{\alpha}=\mathbf{0 , 0 5} ; \mathbf{L}_{\text {tabel }}=\mathbf{0 , 1 7 0 6}\right)$ \\
maka data berdistribusi normal
\end{tabular}




\section{thitung \\ Interpretasi \\ 0,9269 \\ Tidak Terdapat Perbedaan Signifikan}

Hasil perhitungan statistik seperti yang terlihat pada tabel 2. menunjukkan bahwa skor n-gain pemahaman matematis kedua kelas yang diteliti berdistribusi normal dan variansinya homogen. Kemudian dilanjutkan dengan uji perbedaan dua rata-rata untuk sampel bebas (ujit) untuk mengetahui apakah ada perbedaan parameter rata-rata populasi atau tidak.

Setelah dilakukan perhitungan uji-t, hasilnya menyatakan bahwa tidak terdapat perbedaan yang signifikan antara skor $n$-gain kemampuan pemahaman matematis siswa di kelas eksperimen I dan kelas eksperimen II. Hal ini dapat dilihat dari hasil perhitungan dimana $t_{\text {hitung }}=0,9269$ lebih kecil daripada $\mathrm{t}_{(0,05)(50)}=1,6759$. Sehingga melalui uji hipotesis ini dapat dinyatakan bahwa peningkatan kemampuan pemahaman matematis siswa antara kedua perlakuan tidak terdapat perbedaan yang signifikan atau dengan kata lain, baik model pembelajaran think talk write maupun model direct instruction sama efektivitasnya.

\section{Tabel 3. Rekapitulasi Analisis Hasil N-Gain Kemampuan Komunikasi Matematis Siswa}

\begin{tabular}{|c|c|c|}
\hline Komponen Peninjau & $\begin{array}{c}\text { Think Talk Write } \\
\text { (Kelas Eksperimen I) }\end{array}$ & $\begin{array}{c}\text { Direct Instruction } \\
\text { (Kelas Eksperimen II) }\end{array}$ \\
\hline Jumlah Siswa & 26 & 26 \\
\hline$\sum \mathbf{g}$ & 6,961 & 6,268 \\
\hline Rata-rata & 0,2677 & 0,2411 \\
\hline Standar Deviasi & 0,1034 & 0,0952 \\
\hline \multicolumn{3}{|c|}{$\begin{array}{c}\text { Uji Normalitas (Lilliefors) dengan } L_{\text {hitung }}<L_{\text {tabel }}\left(\alpha=0,05 ; L_{\text {tabel }}=0,1706\right) \\
\text { maka data berdistribusi normal }\end{array}$} \\
\hline Lhitung & 0,1475 & 0,1580 \\
\hline Interpretasi & Normal & Normal \\
\hline \multicolumn{3}{|c|}{$\begin{array}{c}\text { Uji Homogenitas }(U j \mathrm{ji}-\mathrm{F}) \text { dengan } \mathrm{F}_{\text {hitung }}<\mathrm{F}_{\text {tabel }}\left(\alpha=0,05 ; \mathrm{db}=25 ; \mathrm{F}_{\text {tabel }}=1,95\right) \\
\text { maka data homogeny }\end{array}$} \\
\hline F hitung & \multicolumn{2}{|c|}{1,1784} \\
\hline Interpretasi & \multicolumn{2}{|c|}{ Varians Homogen } \\
\hline \multicolumn{3}{|c|}{$\begin{array}{c}\text { Uji Hipotesis }(\mathrm{Uji} \text {-t }) \text { dengan } \mathrm{t}_{\text {hitung }}<\mathrm{t}_{\text {tabel }}\left(\alpha=\mathbf{0 , 0 5} ; \mathbf{d f}=\mathbf{f 0} ; \mathrm{t}_{\text {tabel }}=1,6759\right) \\
\text { maka tidak terdapat perbedaan }\end{array}$} \\
\hline$t_{\text {hitung }}$ & \multicolumn{2}{|c|}{0,9663} \\
\hline Interpretasi & \multicolumn{2}{|c|}{ Tidak Terdapat Perbedaan Signifikan } \\
\hline
\end{tabular}

Hasil perhitungan statistik seperti yang terlihat pada tabel 3. menunjukkan bahwa skor $n$-gain kemampuan komunikasi matematis kedua kelas yang diteliti berdistribusi normal dan variansinya homogen. 
Setelah dilakukan perhitungan uji-t, hasilnya menyatakan bahwa tidak terdapat perbedaan yang signifikan antara skor $n$-gain kemampuan komunikasi matematis siswa di kelas eksperimen I dan kelas eksperimen II. Hal ini dapat dilihat dari hasil perhitungan, dimana $t_{\text {hitung }}=0,9663$ lebih kecil daripada $t_{(0,05)(50)}=1,6759$. Sehingga melalui uji hipotesis ini dapat dinyatakan bahwa tidak terdapat perbedaan yang signifikan mengenai peningkatan kemampuan komunikasi matematis siswa antara kelas eksperimen I yang menggunakan model pembelajaran think talk write dengan kelas eksperimen II yang menggunakan model direct instruction, atau dengan kata lain, baik model pembelajaran think talk write maupun model direct instruction sama efektivitasnya.

\section{Pengaruh Model Pembelajaran Think Talk Write dan Model Direct Instruction terhadap Kemampuan Pemahaman dan Komunikasi Matematis Siswa}

Pengujian statistik untuk mengetahui seberapa besar pengaruh model pembelajaran terhadap kemampuan pemahaman dan terhadap kemampuan komunikasi matematis siswa dilakukan dengan analisis skor hasil posttest kedua kelas yang diteliti dengan menggunakan rumus effect size Cohen.

Pengaruh model pembelajaran think talk write dan model direct instruction terhadap kemampuan pemahaman matematis siswa, berdasarkan hasil analisis didapat nilai $\mathrm{d}=0,205$ dan termasuk ke dalam klasifikasi rendah. Dengan demikian interpretasi effect size yang didapat adalah sebesar $14,7 \%$. Artinya pengaruh model pembelajaran think talk write dan model direct instruction terhadap kemampuan pemahaman matematis siswa adalah sebesar $14,7 \%$.

Sedangkan pengaruh model pembelajaran think talk write dan model direct instruction terhadap kemampuan komunikasi matematis siswa, berdasarkan hasil analisis didapat nilai d $=0,291$ dan termasuk ke dalam klasifikasi rendah. Dengan demikian interpretasi effect size yang didapat adalah sebesar $21,3 \%$. Artinya pengaruh model pembelajaran think talk write dan model direct instruction terhadap kemampuan komunikasi matematis siswa adalah sebesar $21,3 \%$.

\section{G. Pembahasan}

Dari hasil skor pretest dan posttest yang diberikan kepada siswa di kelas eksperimen I dan kelas eksperimen II, menunjukkan bahwa perbandingan kemampuan pemahaman matematis siswa di kelas eksperimen I sedikit lebih baik dibandingkan siswa di kelas 
eksperimen II. Demikian juga dengan perbandingan kemampuan komunikasi matematis. Siswa di kelas eksperimen I mempunyai kemampuan komunikasi yang sedikit lebih baik daripada siswa di kelas eksperimen II, walaupun perbedaannya tidak signifikan. Temuan ini menunjukkan bahwa siswa pada kedua kelas yang diteliti mempunyai kemampuan yang setara. Hal ini memenuhi karakteristik penelitian eksperimen yang dikemukakan Ruseffendi (2010) bahwa, kesetaraan subjek penelitian dalam kelompok-kelompok yang berbeda perlu ada, agar hasil yang diperoleh kelompok bila berbeda bukan disebabkan karena tidak ekuivalennya kelompok-kelompok tersebut, tetapi karena adanya perlakuan yang berbeda.

Peningkatan kemampuan pemahaman matematis antara siswa yang menggunakan model pembelajaran think talk write dengan siswa yang menggunakan model direct instruction tidak terdapat perbedaan yang signifikan. Demikian juga dengan peningkatan kemampuan komunikasi matematis, tidak terdapat perbedaan yang signifikan antara siswa yang menggunakan model pembelajaran think talk write dengan siswa yang menggunakan model direct instruction. Artinya, pengaruh dari perlakuan yang diberikan kepada kedua kelas, baik kelas eksperimen I maupun kelas eksperimen II menghasilkan dampak yang sama. Hal ini dapat dilihat dari analisis gain ternormalisasi dari hasil pretest dan posttest soal kemampuan pemahaman dan kemampuan komunikasi matematis siswa. Dari hasil analisis uji normalitas, homogenitas, dan uji hipotesis n-gain kemampuan pemahaman dan komunikasi matematis, didapatkan data yang berdistribusi normal, bervariansi homogen, dan tidak terdapat perbedaan yang signifikan antara siswa yang diberi perlakuan dengan menggunakan model pembelajaran think talk write dan yang menggunakan model direct instruction.

Walaupun secara statistik kemampuan pemahaman dan komunikasi matematik siswa tidak terdapat perbedaan yang signifikan antara kedua kelas yang diteliti, namun untuk kemampuan pemahaman matematis, siswa yang menggunakan model direct instruction memiliki nilai pencapaian yang lebih baik dibandingkan siswa yang menggunakan model pembelajaran think talk write. Hal ini bisa dilihat dari hasil rata-rata $n$-gain, dimana siswa yang menggunakan model direct instruction rata-rata n-gainnya lebih besar daripada siswa yang menggunakan model pembelajaran think talk write. Sebaliknya, untuk kemampuan komunikasi matematis, siswa yang menggunakan model pembelajaran think talk write memiliki nilai pencapaian yang lebih baik dibandingkan siswa yang menggunakan model direct instruction. Hal ini bisa dilihat dari hasil rata-rata $n$-gain, dimana siswa yang menggunakan model pembelajaran think talk write rata-rata n-gainnya lebih besar daripada siswa yang menggunakan model direct instruction. 
Pengaruh model pembelajaran think talk write dan model direct instruction terhadap kemampuan pemahaman matematis siswa dalam penelitian ini termasuk ke dalam klasifikasi rendah yaitu sebesar $14,7 \%$. Sedangkan pengaruh model pembelajaran think talk write dan model direct instruction terhadap kemampuan komunikasi matematis siswa dalam penelitian ini juga termasuk ke dalam klasifikasi rendah yaitu sebesar 21,3\%. Hal ini mungkin disebabkan oleh waktu penelitian yang singkat, yaitu hanya dilakukan selama enam kali pertemuan, sehingga waktu adaptasi siswa terhadap kedua model pembelajaran ini kurang maksimal. Dalam kerja kelompok juga seringkali interaksi yang terjadi kurang maksimal, karena terlalu didominasi oleh siswa yang mampu, sehingga siswa yang kemampuannya kurang kehilangan kepercayaan diri dan seringkali hanya menjadi penonton. Tingkat kesukaran soal yang tinggi juga berkontribusi terhadap rendahnya pengaruh model pembelajaran terhadap kemampuan pemahaman dan komunikasi matematis siswa.

Dengan demikian, model pembelajaran think talk write dan model direct instruction dapat digunakan sebagai alternatif model dalam pembelajaran matematika di sekolah dasar. Kemampuan guru dalam menggunakan model pembelajaran yang dapat membangkitkan semangat siswa merupakan suatu keharusan agar proses belajarnya semakin menyenangkan. Tingkat pemahaman siswa dalam kemampuan matematisnya perlu ditunjang oleh kemampuan komunikasinya, karena kedua hal ini sangatlah berhubungan. Dengan kemampuan komunikasi matematis siswa mampu menyampaikan konsep-konsep matematis kepada orang lain sebagai informasi. Oleh karena itu, kedua model ini memberikan kontribusi yang positif bagi kemajuan dan peningkatan proses belajar siswa sehingga hasil belajar matematikanya meningkat.

\section{H. Simpulan}

Kemampuan pemahaman dan komunikasi matematis siswa merupakan dua hal yang sangat berkaitan dan perlu mendapatkan perhatian pada saat proses pembelajaran. Simpulan yang dapat diambil dari hasil penelitian yang telah dilakukan antara lain sebagai berikut.

1. Tidak terdapat perbedaan peningkatan kemampuan pemahaman matematis secara signifikan antara siswa yang menggunakan model pembelajaran think talk write dengan siswa yang menggunakan model direct instruction.

2. Tidak terdapat perbedaan peningkatan kemampuan komunikasi matematis secara signifikan antara siswa yang menggunakan model pembelajaran think talk write dengan siswa yang menggunakan model direct instruction. 
3. Pengaruh (effect size) model pembelajaran think talk write dan model direct instruction terhadap kemampuan pemahaman matematis siswa termasuk klasifikasi rendah.

4. Pengaruh (effect size) model pembelajaran think talk write dan model direct instruction terhadap kemampuan komunikasi matematis siswa termasuk klasifikasi rendah.

\section{Daftar Pustaka}

Arends, R. I. (2007). Learning to teach (belajar untuk mengajar). Diterjemahkan oleh Helly Prayitno Soetjipto dan Sri Mulyantini Soetjipto. Jakarta: Pustaka Pelajar.

Becker, L. (2000). Effect size calculators. College of Letters, Ads, and Sciences. University of Colorado, Colorado Springs. [Online]. Diakses dari: http://www.uccs.edu/lbecker/effect-size.html.[15 Juni 2016, 9:17].

Hamzah, A., \& Muhlisrarini. (2014). Perencanaan dan strategi pembelajaran matematika. Jakarta: PT. RajaGrafindo Persada.

Huinker, D., \& Laughlin, C. (1996). Talk your way into writing. P.C. Elliot, \& M.J. Kenney (Ed.), Communication in Mathematics: K"12 and Beyond. Yearbook of the National Council of Teachers of Mathematics.

Joyce, B., Weil, M., \& Calhoun, E., (2009). Models of teaching. Yogyakarta: Pustaka Pelajar.

Marpaung, Y.(1999).Struktur kognitif dalam pembentukan konsep algoritma matematis. Dimuat dalam kumpulan Makalah FMIPA IKIP Sanata Dharma Yogyakarta. Editor: Y. Marpaung, Paul Suparno.

Panggabean, L. P. (1996). Penelitian pendidikan. Bandung: Jurusan Pendidikan Fisika FPMIPA UPI.

Peraturan Menteri No. 23 Tahun 2006 Tentang Standar Kompetensi Lulusan.

Porter, B. (1992). Quantum learning. Bandung: Kaifa.

Ruseffendi, E.T. (2006). Pengantar kepada membantu guru mengembangkan kompetensinya dalam pengajaran matematika untuk meningkatkan cara belajar siswa aktif (CBSA). Bandung: Tarsito. 
Soedjadi. (2000). Kiat pendidikan matematika di Indonesia. Jakarta: Direktorat Jenderal Pendidikan Tinggi Departemen Pendidikan Nasional.

Sugiono. (2014). Metode penelitian kuantitatif kualitatif dan $R \& D$. Bandung: Alfabeta.

Sumarmo, U. (1987). Kemampuan pemahaman dan penalaran matematika siswa SMA dikaitkan dengan kemampuan penalaran logik siswa dan beberapa unsur proses belajar mengajar. Disertasi. FPs IKIP Bandung: Tidak diterbitkan.

Sumarmo, U. (2007). Pembelajaran matematika dalam rujukan filsafat, teori dan praktis ilmu pendidikan. (Natawidjaja R, Sukmadinata, Ibrahim R, Djohar A, Editor). Bandung: UPI Press.

Tandilling, E. (2012). Pengembangan instrumen untuk mengukur kemampuan komunikasi matematik, pemahaman matematik, dan self-regulated learning siswa dalam pembelajaran matematika di sekolah menengah atas. Jurnal Penelitian Pendidikan, Vol. 13, No. 01, April, hal: 24-31.

Wahyudin. (2012). Filsafat dan model-model pembelajaran matematika. Bandung: Mandiri.

Wardhani, S. (2008).Analisis SI dan SKL mata pelajaran matematika SMP/MTs untuk optimalisasi mata pelajaran matematika. Yogyakarta: Departemen Pendidikan Nasional. 